\title{
Short Communication: A checklist of the mosquito species (Diptera: Culicidae) in the Suan Phueng District, Ratchaburi Province, Thailand
}

\author{
TANAWAT CHAIPHONGPACHARA \\ ${ }^{1}$ College of Allied Health Science, Suan Sunandha Rajabhat University. Samut Songkhram 75000, Thailand \\ Tel./fax. +66-835-865775, `email: tanawat.ch@ssru.ac.th
}

Manuscript received: 26 December 2018. Revision accepted: 26 January 2019.

\begin{abstract}
Chaiphongpachara T. 2019. Short Communication: A checklist of the mosquito species (Diptera: Culicidae) in the Suan Phueng District, Ratchaburi Province, Thailand. Biodiversitas 20: 468-473. Mosquito is a medically important insect, which is a vector to transmit pathogens to humans. There are several methods to reduce the numbers mosquitoes, which requires entomological knowledge. It is critical to know the species of mosquitoes in the area to choose the most suitable method to provide vector control, specifically, to target mosquito species. In this study, we investigated the species of mosquito vectors in the Huay Nam Nak Village in the Suan Phueng District, Ratchaburi Province, Thailand, which is an endemic area of mosquito-borne diseases, especially malaria and dengue fever. Mosquito species were collected by the Mosquito Magnet® Independence trap from the Huay Nam Nak Village. A total of 1,002 mosquitoes, divided into eight species in four genera, including Anopheles barbirostris s.l. van der Wulp (118 individuals), An. subpictus s.l. Grassi (127 individuals), Culex quinquefasciatus Say (186 individuals), Cx. vishnui Theobald (204 individuals), Cx. whitmorei Giles (198 individuals), Aedes aegypti Linnaeus (45 individuals), Ae. albopictus Skuse (78 individuals), and Armigeres subalbatus Coquillett (46 individuals). This checklist of the mosquito species is very important information to set mosquito control measures that suit each area.
\end{abstract}

Keywords: Checklist, mosquito, Diptera, Thailand

\section{INTRODUCTION}

The mosquito is a medically important insect, which is a vector to transmit pathogens to humans (World Health Organization 2016). Usually, female mosquitoes must take blood meals for the development of their eggs, while male mosquitoes feed on flower nectar. The blood-feeding characteristics of the female mosquito are behavior that leads pathogens, including protozoan parasites, nematodes, and viruses to humans (Rodriguez et al. 2015). Mosquitoborne diseases are major public health issues and include malaria, dengue, Japanese encephalitis (JE), and filariasis. Currently, these mosquito-borne diseases are often present (endemic), especially in tropical and sub-tropical countries (World Health Organization 2016).

Malaria is caused by the Plasmodium protozoan, which is transmitted to humans from Anopheles mosquitoes (Cox 2010). Globally, there are more than one million cases of malaria every year, mostly in Africa, with were many outbreaks in Asia as well (Hay et al. 2004). Dengue is an infectious disease caused by the dengue virus (DENV), and there were approximately 50-100 million infected populations worldwide (Guo et al. 2017). JE is one of the most important viral brain infections in Asia, with an estimated 68,000 clinical cases per year, and is spread by $C u l e x$ mosquitoes, mainly $C x$. tritaeniorhynchus. Lymphatic filariasis (or elephantiasis) is also a major public health problem. In 2000, over 120 million people were infected. This disease is caused by filarial nematodes, including Wuchereria bancrofti and Brugia malayi, and is transmitted by many types of mosquitoes, including Culex, Aedes, Anopheles, and Mansonia (Ngwira et al. 2007).

Thailand is located in a tropical area where mosquitoborne diseases are also major problems. In Thailand, mosquito vectors belong to the genera Culex, Aedes, Anopheles, and Mansonia species. The Bureau of Epidemiology, Thailand, in 2016, reported 5,273 malaria cases, $14 \mathrm{JE}$ cases, 4 filariasis cases, and 38,466 dengue fever cases, which pointed to urgent problems that must be addressed (Ministry of Public Health 2016).

Ratchaburi Province, located in the west of Thailand, including some parts of the Thailand-Myanmar border area, and is an endemic area of mosquito-borne diseases (Chaiphongpachara 2018). In 2016, reports from the Bureau of Epidemiology found 77 malaria cases, 264 dengue fever cases (Ministry of Public Health 2016). The border area of this province are high mountainous areas and have abundant forest resources that cause the outbreak of malaria as it is an Anopheles habitat.

Control of mosquito vectors in the endemic area is a highly effective way of controlling mosquito-borne diseases (Chaiphongpachara 2018; Chaiphongpachara $\mathrm{T}$ et al. 2018). There are several other methods to reduce the number of mosquitoes, which require entomological knowledge (Chaiphongpachara et al. 2018). The species of mosquitoes in an area is a must to know how to choose the most suitable method to vector control, which must be specific to target mosquito species (Chaiphongpachara and 
Sumruayphol 2017). In each area, there is a different environment and habitat for mosquitoes that depend on the genus and species, such as the breeding site of the Aedes aegypti L. For example, the dengue fever vector is found in artificial water containers in houses (Chaiphongpachara et al. 2017) the $C x$. tritaeniorhynchus Giles as the JE vector is found in paddy fields, An. dirus Peyton and Harrison as malaria vectors are found in deep-forested areas, and $M a$. dives Schiner as the Brugia malayi filariasis vector is found in swamp areas (Rattanarithikul et al. 2005).

In this study, we investigated the species of mosquito vectors in the Huay Nam Nak Village in Suan Phueng District, Ratchaburi Province, Thailand, which is an endemic area of mosquito-borne diseases, especially malaria and dengue fever. Although the Huay Nam Nak Village is an outbreak area of mosquito-borne diseases, the list of mosquito vectors in this area remains unclear. This survey is important information for medical entomology to determine how to control mosquitoes in the area.

\section{MATERIALS AND METHODS}

\section{Study site}

Mosquitoes species were collected by the Mosquito Magnet ${ }^{\circledR}$ Independence (MMI) trap (Wood stream Corporation, Lititz, USA) in the Huay Nam Nak Village (1322'26.6"N 99 16'14.3"E), Suan Phueng District, Ratchaburi Province, Thailand (Figure 1). A total of four traps were used in this study once a week during the rainy season from August-November 2016. The MMI traps were placed 100 meters away from homes and trapped for 24 hours. Trapping homes were selected randomly using a table of random numbers.
After the trapping, we counted, recorded, and then sent mosquitoes to the laboratory at the College of Allied Health Sciences, Suan Sunandha Rajabhat University, Samut Songkhram Education Center, Thailand for species identification.

\section{Mosquitoes species identification}

The collected mosquitoes from the field were identified under a Nikon AZ 100 M stereomicroscope (Nikon Corp., Tokyo, Japan) by morphology using the Illustrated Keys to the Mosquitoes in Thailand (Rattanarithikul et al. 2005). Before identification, mosquitoes were placed inside a 1.5 $\mathrm{ml}$ micro-centrifuge tube labelled with codes and were placed inside a cardboard box and stored under- $20^{\circ} \mathrm{C}$ freezer.

\section{Data analysis}

Each species of mosquito presented a mean with standard deviation and percentage. Mosquito vectors found in the Huay Nam Nak Village are described in the literature review (Rattanarithikul et al. 2005).

\section{RESULTS AND DISCUSSION}

\section{A checklist of the mosquito species}

A total of 1,002 mosquitoes were divided into eight species in four genera, including Anopheles barbirostris s.l. van der Wulp (118 individuals), An. subpictus s.l. Grassi (127 individuals), Culex quinquefasciatus Say (186 individuals), $C x$. vishnui Theobald (204 individuals), $C x$. whitmorei Giles (198 individuals), Aedes aegypti Linnaeus (45 individuals), Ae. albopictus Skuse (78 individuals), and Armigeres subalbatus Coquillett (46 individuals) (Table 1).

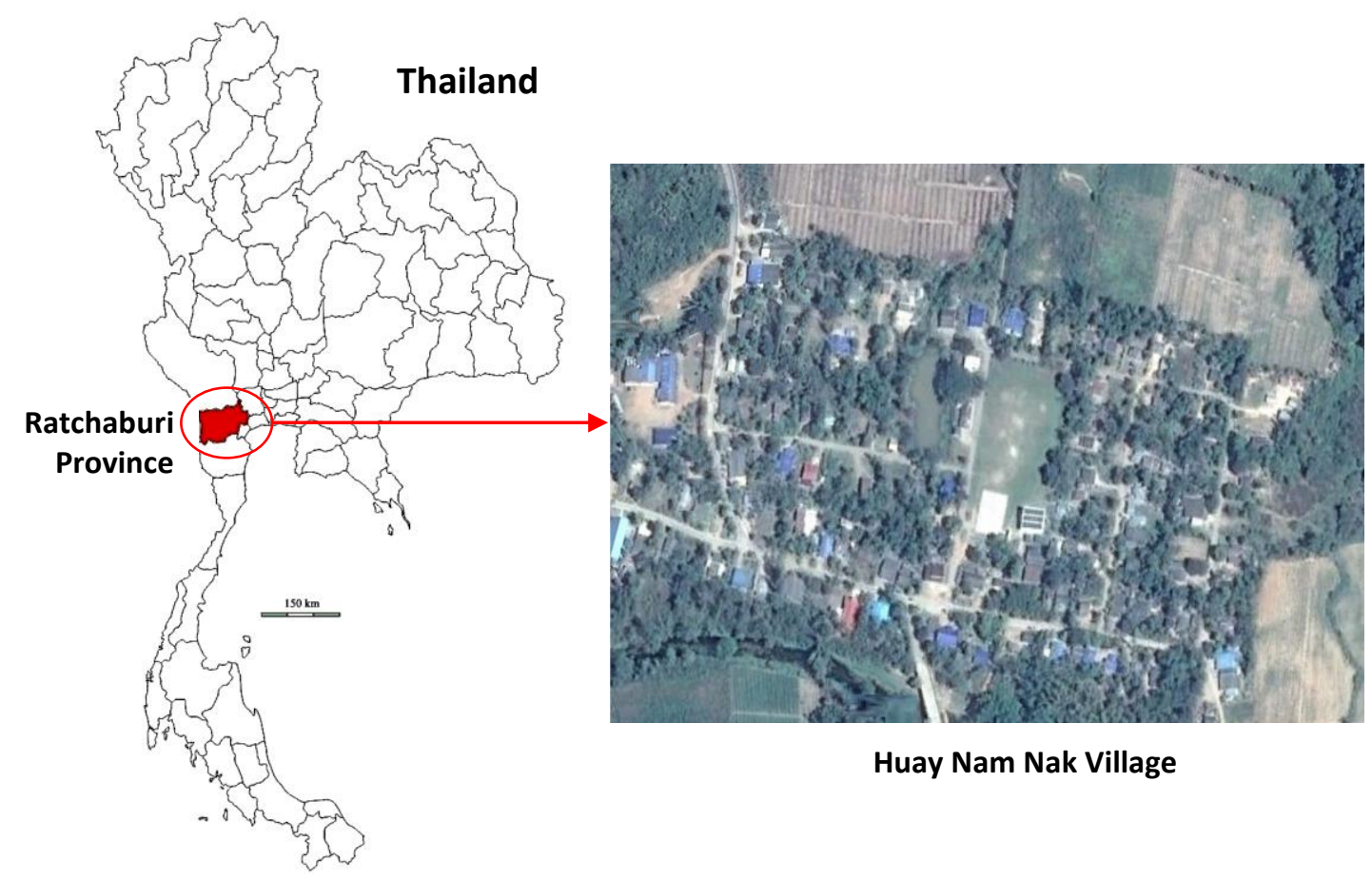

Figure 1. The surveyed area in Huay Nam Nak Village, Suan Phueng District, Ratchaburi Province, Thailand 
Table 1. The checklist of the mosquito species in Huay Nam Nak Village, Ratchaburi Province, Thailand.

\begin{tabular}{|c|c|c|c|}
\hline Species & $\begin{array}{c}\text { Mean } \pm \text { S.D. } \\
\text { (numbers/ night) }\end{array}$ & $\begin{array}{l}\text { Percentage of mosquito } \\
\text { species }\end{array}$ & $\begin{array}{c}\mathrm{n} \\
\text { (12 days) }\end{array}$ \\
\hline An. barbirostris s.l. van der Wulp & $9.83 \pm 3.59$ & 11.77 & 118 \\
\hline An. subpictus s.l. Grassi & $10.58 \pm 5.23$ & 12.67 & 127 \\
\hline Cx. quinquefasciatus Say & $15.50 \pm 7.47$ & 18.56 & 186 \\
\hline Cx. vishnui Theobald & $17.00 \pm 7.53$ & 20.36 & 204 \\
\hline Cx. whitmorei Giles & $15.50 \pm 8.66$ & 19.76 & 198 \\
\hline Ae. aegypti Linnaeus & $3.75 \pm 2.99$ & 4.49 & 45 \\
\hline Ae. albopictus Skuse & $6.50 \pm 3.58$ & 7.78 & 78 \\
\hline Ar. subalbatus Coquillett & $3.83 \pm 2.17$ & 4.61 & 46 \\
\hline Total & $83.50 \pm 19.67$ & 100 & 1,002 \\
\hline
\end{tabular}

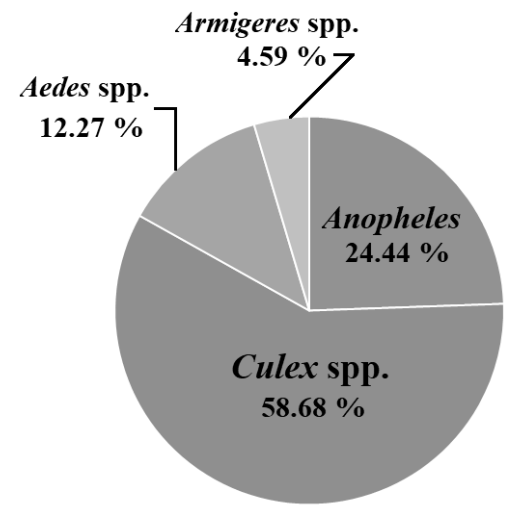

Figure 2. Percentage of mosquito genera in Huay Nam Nak Village, Suan Phueng District, Ratchaburi Province, Thailand

We collected mosquito vectors using MMI during the rainy season, which trapped an average of 83.50 individual mosquitoes per night (Table 1). The mosquito species in genus Culex was found the most in this area $(58.68 \%)$ while mosquito species in genus Armigeres was found least $(4.59 \%)$ (Figure 2). Each night, $C x$. vishnui was the most collected species, with an average of 17 individuals, followed by $C x$. whitmorei, $C x$. quinquefasciatus, $A n$. subpictus s.l., An. barbirostris s.l., Ae. albopictus, Ar. subalbatus, and Ae. aegypti, respectively (Table 1).

\section{Morphology of founded mosquito vectors \\ Nocturnal mosquito vectors}

Anopheles barbirostris sensu lato (s.l.) van der Wulp is a species complex that belongs to the Barbirostris subgroup (Figure 3A,Wang et al. 2014). This species complex consists of more than five members whose habitats are each quite diverse (Taai and Harbach 2015). An. barbirostris sensu stricto (s.s.) is the most common species and is a more medically important vector than other members in the $A n$. barbirostris complex. An. barbirostris s.s. is a suspected vector of Plasmodium spp., a malaria pathogen in Thailand (Sriwichai et al. 2016). The important characteristics of An. barbirostris s.l. are that "the wing has less than four dark areas on the vein costa and the antennal sternum has seven tufts on dark scales (Rattanarithikul et al. 2006)".
Anopheles subpictus s.l. Grassi (Figure 3B) is a species complex and consists of four members, including species A, B, C, and D (Chandra et al. 2010) . An. subpictus s.l. is the most abundant in the Indian subcontinent, with a widespread distribution east and south to Papua, New Guinea, west to Iran, and north to China (Chandra et al. 2010). This complex is not a vector in Thailand but is a secondary vector of malaria in Sri Lanka. The important characteristics of members in this complex are "the hind femur, tibia, and tarsomere, one dark, not speckled, with pale scales. In addition, the maxillary palpus with an apical pale band of 2.5 times, with a subapical pale band of 0.33 , or less the length of the preapical dark band (Rattanarithikul et al. 2006)".

Culex quinquefasciatus Say (Figure 3C) spreads throughout the world, especially in tropical and subtropical areas and is associated with human dwellings. In Thailand, $C x$. quinquefasciatus in a vector of filariasis and JE. The important characteristics of $C x$. quinquefasciatus is "a proboscis without a pale ring, abdominal terga with basal pale markings, and thoracic pleura without a distinct striking pattern of dark and pale bands (Rattanarithikul et al. 2005)".

Culex vishnui Theobald is a significant vector of JE (Figure 3D). The important characteristics of $C x$. vishnui is "a vertex with erect light brown to dark scales and scutum entirely covered by light brown dark scales, anterior surfaces of thr hind femur with an apical dark band, not contrasting with the pale scaled area (Rattanarithikul et al. 2005)".

Culex whitmorei Giles is also an important vector of JE (Figure 3E). The important characteristics of this species of Culex are that they have "a vertex with erect white scales and scutum with an anterior patch of white scales. On the leg, the anterior surfaces of fore-and mid-femora are speckled with pale scales (Rattanarithikul et al. 2005)".

Armigeres subalbatus Coquillett is reported as a vector of the JE virus, a filarial worm, such as Wuchereria bancrofti and Brugia pahangi, and dog heartworm, Dirofilaria immitis. Ar. subalbatus, are widely distributed throughout Southeast and East Asia and are usually found near human dwellings, especially in urban and rural areas with poor sanitation. The important characteristics of this species are that "the proboscis gradually curves downward and is laterally compressed, and the dorsal scales on the wing veins are not broad (Rattanarithikul et al. 2005)". 


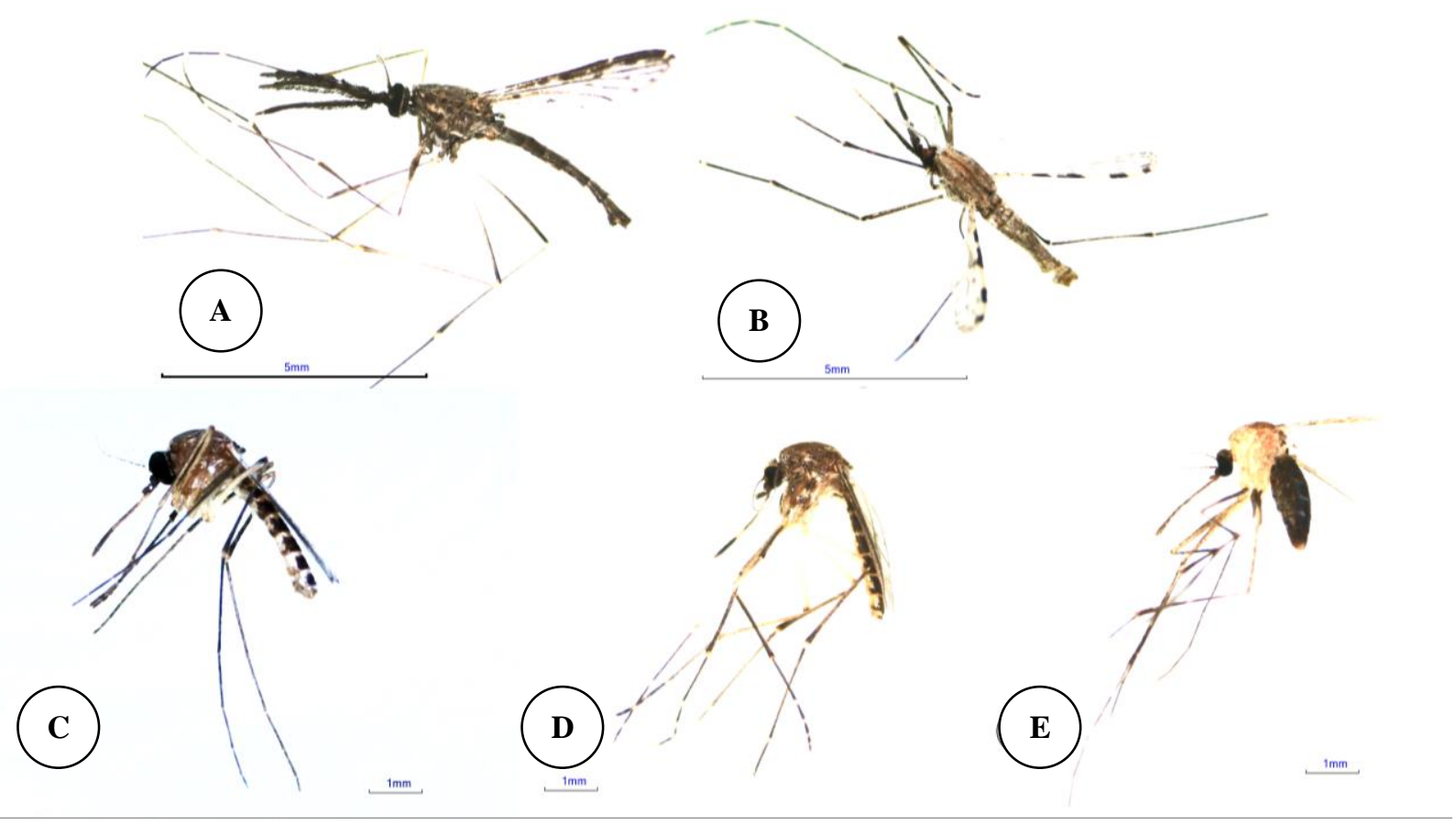

Figure 3. Nocturnal mosquito vectors found in Huay Nam Nak Village. (A: An. barbirostris s.l. van der Wulp, B: An. subpictus s.l. Grassi, C: Cx. quinquefasciatus Say, D: Cx. vishnui Theobald, E: Cx. whitmorei Giles)

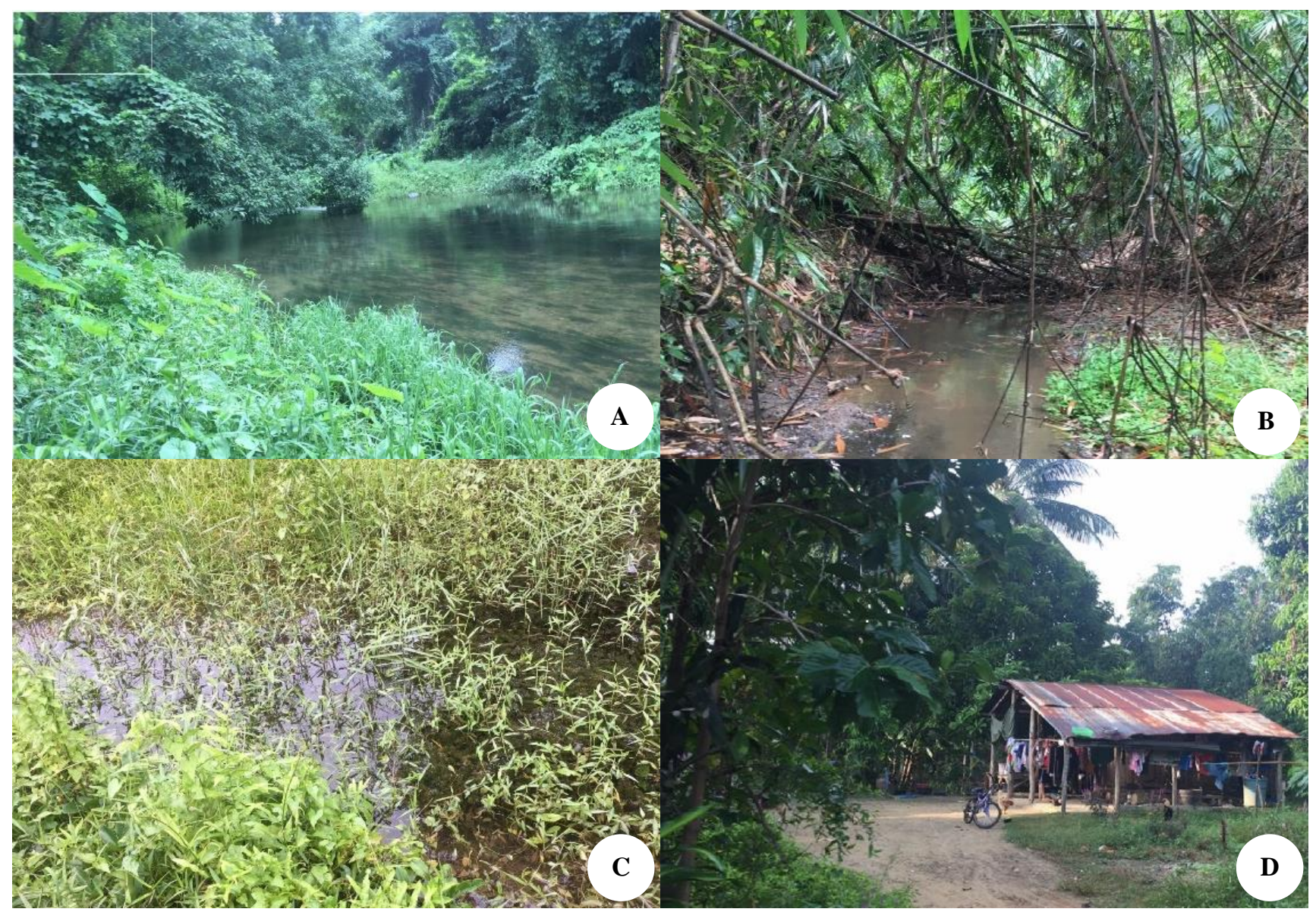

Figure 4. Types of breeding sites of mosquito vectors in Huay Nam Nak Village, Suan Phueng District, Ratchaburi Province. A. Lam Pachi River, B. Small stream, C. Flood pool, D. People's homes 


\section{Diurnal mosquito vectors}

Aedes aegypti Linnaeus originated in Africa and is the primary species responsible for transmitting three important viral diseases, including dengue, chikungunya and yellow fever viruses. They mainly occur in tropical and sub-tropical regions. Generally, the Aedes mosquito species are active during the daytime (Service 2008). The important morphological characteristics of the Ae. aegypti are "scutum with lyre-shaped white markings and clypeus with lateral white scale patches (Rattanarithikul et al. 2010)", which is different from other Aedes mosquitoes.

Aedes albopictus Skuse is a vector of chikungunya and dengue viruses and is active during the daytime as well (Service 2008). The important characteristics of this species of Aedes mosquito are "a scutum with a long median longitudinal stripe of white scales and tibiae without a median white band (Rattanarithikul et al. 2010)", which is different from other Aedes mosquitoes.

This study relayed a new checklist of mosquito species vectors in Huay Nam Nak Village, Suan Phueng District, Ratchaburi Province. Ratchaburi Province as this is an endemic area on the Thai-Myanmar border for mosquitoborne diseases, especially dengue fever and malaria (Chaiphongpachara 2018). Species of mosquitoes in each area effect the outbreak of mosquito-borne diseases (Möhlmann et al. 2018). Vector competence is the ability of arthropods to acquire, maintain, and transmit pathogens, which is one of the factors contributing to the importance of mosquitoes as vectors (Goddard et al. 2002). Mosquito vectors are associated with the environment and ecology in each area where the same mosquito species are primary vectors in some areas, but only a secondary vector in other areas (Service 2008). An. subpictus s.l. is one of eight species of found mosquitoes in this study which is a secondary malaria vector in Sri Lanka, but not in Thailand. While we did not find a primary malaria vector in this study, including An. dirus Peyton \& Harrison, An. minimus Theobald, and An. maculatus Theobald, An. barbirostris s.l. was found and is a suspected vector of malaria.

In this checklist, we found 1,002 mosquitoes, divided into eight species, belonging to four genera, of which seven species of mosquito were reported to be vectors in Thailand, including An. barbirostris s.l., Cx quinquefasciatus, $C x$. vishnui, Cx. whitmorei, Ae aegypti, Ae. albopictus, and Ar. subalbatus. The Huay Nam Nak Village is located at the edge of the forest and the Lam Pachi River flows through it. We explored this river and a small stream and found them to be important breeding sites for mosquito larvae of $A n$. barbirostris s.l. An. subpictus s.1., Cx quinquefasciatus, $C x$. vishnui, and $C x$. whitmorei (Figures 4A-B). The flood pool is a breeding site for Culex mosquitoes, including $C x$ quinquefasciatus, $C x$. vishnui, and $C x$. whitmorei in this area (Figure 4C). For Aedes mosquitoes, including Ae. aegypti and Ae. albopictus, these were found in water containers in people's homes (Figure 4D).

In conclusion, this checklist of the mosquito species is very important information to set measures to control mosquitoes that suits each area. The results of this study show that the area has mosquito vectors of four major diseases, including malaria, dengue, JE, and filariasis. Hence, providing health education and knowledge to populations about the protection from these mosquitoes is essential. In addition, the reduction of mosquitoes in the area is important, such as with the use of mosquito traps or the destruction of breeding sites.

\section{ACKNOWLEDGEMENTS}

The author would like to acknowledge the influence that the College of Allied Health Sciences, Suan Sunandha Rajabhat University, Thailand.

\section{REFERENCES}

Chaiphongpachara T, Padidpoo O, Chansukh KK, Sumruayphol S. 2018. Efficacies of five edible mushroom extracts as odor baits for resting boxes to attract mosquito vectors : A field study in Samut Songkhram Province, Thailand. Trop Biomed 35: 653-663.

Chaiphongpachara T. 2018. Comparison of landmark-and outline-based geometric morphometrics for discriminating mosquito vectors in Ratchaburi Province, Thailand. Biomed Res Intl. DOI: $10.1155 / 2018 / 6170502$.

Chaiphongpachara T, Bunyuen P, Chansukh KK. 2018. Development of a more effective mosquito trapping box for vector control. Sci World J. DOI: $10.1155 / 2018 / 6241703$

Chaiphongpachara T, Laojun S, Kunphichayadecha Ch . 2018. Effect of the CDC light trap on control of nocturnal mosquitoes in coastal Samut Songkhram Province, Thailand. Biodiversitas 19: 1750-1754.

Chaiphongpachara T, Pimsuka S, Saisanan Na Ayudhaya W, Wassanasompon W. 2017. The application of geographic information system in dengue haemorrhagic fever risk assessment in Samut songkhram Province, Thailand. Intl J Geomate 12: 53-60.

Chaiphongpachara T, Sumruayphol S. 2017. Species diversity and distribution of mosquito vectors in coastal habitats of Samut Songkhram province, Thailand. Trop Biomed 34: 524-532.

Chandra G, Bhattacharjee I, Chatterjee S. 2010. A review on Anopheles subpictus Grassi-A biological vector. Acta Tropica. DOI: 10.1016/j.actatropica.2010.02.005

Cox FE. 2010. History of the discovery of the malaria parasites and their vectors. Parasit Vectors. DOI: 10.1186/1756-3305-3-5.

Goddard LB, Roth AE, Reisen WK, Scott TW. 2002. Vector competence of California mosquitoes for West Nile virus. Emerg Infect Diseases. DOI: 10.3201/eid0812.

Guo C, Zhou Z, Wen Z, Liu Y, Zeng C, Xiao D, Yang G. 2017. Global Epidemiology of Dengue Outbreaks in 1990-2015: A systematic review and meta-analysis. Front Cell Infect Microbiol, 7; 1-11.

Hay SI, Guerra CA, Tatem AJ, Noor AM, Snow RW. 2004. The global distribution and population at risk of malaria: Past, present, and future. Lancet Infect Dis. DOI: 10.1016/S1473-3099(04)01043-6.

Ministry of Public Health, Thailand. 2016. Annual report. Bureau of Vector Borne Disease. www.thaivbd.org/n/home.com.

Möhlmann TWR, Wennergren U, Tälle M, Favia G, Damiani C, Bracchetti L, Koenraadt CJM. 2018. Community analysis of the abundance and diversity of biting midge species (Diptera: Ceratopogonidae) in three European countries at different latitudes. Parasit Vectors. DOI: 10.1186/s13071-018-2792-x.

Ngwira BMM, Tambala P, Maria AM, Bowie C, Molyneux DH. 2007. The geographical distribution of lymphatic filariasis infection in Malawi. Filaria J. DOI: 10.1186/1475-2883-6-12.

Rattanarithikul R, Harbach RE, Harrison BA, Panthusiri P, Coleman RE, Richardson JH. 2010. Illustrated keys to the mosquitoes of Thailand. VI. Tribe Aedini. Southeast Asian J Trop Med. DOI: 10.1186/17563305-3-5.

Rattanarithikul R, Harrison BA, Harbach RE, Panthusiri P, Coleman RE. 2006. Illustrated keys to the mosquitoes of Thailand IV. Anopheles. Southeast Asian J Trop Med. DOI: 10.1088/0004-637X/709/2/937. 
Rattanarithikul R, Harrison BA, Panthusiri P, Coleman RE, 2005. Illustrated keys to the mosquitoes of Thailand. I. Background; geographic distribution; lists of genera, subgenera, and species; and a key to the genera. Southeast Asian J Trop Med 36: 1-80.

Rodriguez SD, Drake LL, Price DP, Hammond JI, Hansen IA, Liu N. 2015. The efficacy of some commercially available insect repellents for Aedes aegypti (Diptera: Culicidae) and Aedes albopictus (Diptera: Culicidae). J Insect Sci. DOI: 10.1093/jisesa/iev125.

Service M. 2008. Medical Entomology for Students. 4th ed. Cambridge University Press, UK.

Sriwichai P, Samung Y, Sumruayphol S, Kiattibutr K, Kumpitak C, Payakkapol A, Sattabongkot J. 2016. Natural human Plasmodium infections in major Anopheles mosquitoes in western Thailand. Parasit Vectors 9:17. DOI: 10.1186/s13071-016-1295-x.

Taai K, Harbach RE. 2015. Systematics of the Anopheles barbirostris species complex (Diptera: Culicidae: Anophelinae) in Thailand. Zool J Linn Soc. DOI: 10.1111/zoj.12236.

Wang Y, Xu J, Ma Y. 2014. Molecular characterization of cryptic species of Anopheles barbirostris van der wulp in China. Parasit Vectors. DOI: $10.1186 / \mathrm{s} 13071-014-0592-5$.

World Health Organization. 2016. Mosquito born diseases. www.who.int/neglected_diseases/vector_ecology/mosquito-bornediseases/en/.com 